\title{
Shinnery Oak Poisoning Of Rangeland Cattle: Causes, Effects \& Solutions
}

\author{
By Lance T. Vermeire and David B. Wester
}

\author{
Shinnery oak in the Southwest can reduce livestock performance and \\ even lead to death. Here are strategies to recognize \\ shinnery oak poisoning and treat or prevent it.
}

$\mathrm{O}$ ak poisoning has been reported for many species of animals around the world, but the majority of cases involve cattle in the American Southwest. Results of poisoning range from reduced livestock performance to wide-spread mortality. Oak poisoning caused an estimated annual loss of $\$ 10$ million to the Texas cattle industry alone during the early 1960s.

Sand shinnery oak is a low-growing shrub that can dominate sandy soils in the southern Great Plains. It is very accessible to cattle and one of three oak species most commonly involved in livestock poisoning.

\section{Distribution, Phenology And Associated Vegetation}

Shinnery oak is a native shrub of sandy sites in western Oklahoma, the southern High Plains of Texas, and eastern New Mexico (Fig. 1). Shin oak occurs within the same region and appears similar to shinnery oak, but is restricted to limestone soils. Sites dominated by shinnery oak typically have highly permeable soils of low fertility, and are subject to wind erosion. Shinnery oak density, height, and cover are inversely related to surface soil clay content and positively related with depth to a clayey horizon.

Shinnery communities are dominated by shinnery oak and tallgrasses. Dominant grass species include big bluestem, little bluestem, switchgrass, giant dropseed, and sand dropseed. Sand sagebrush, sand plum, and skunkbush sumac are co-dominant shrubs and prominent forbs include annual buckwheat and western ragweed. Shinnery communities are relatively productive because the sandy soils provide better soil moisture than heavier-textured soils in the same precipitation zone. The dominant grasses are generally desirable cattle forages and the diversity of forbs

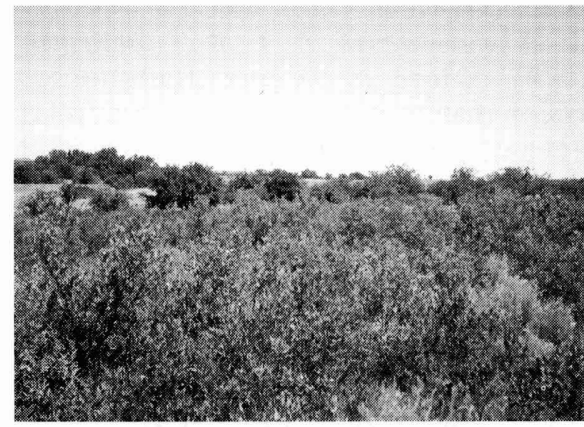

and shrub cover in these sandy communities provides good habitat for numerous species of wildlife.

Shinnery bud burst occurs in midMarch, with full leaf development and flowering during April and May. Acorns are up to 1 inch long and mature in a single season, providing a valuable food source for many species of wildlife. Plants remain physiologically active until October or late November.

\section{Effects Of Oak Poisoning}

Shinnery-dominated rangeland is commonly grazed by livestock (primarily cattle) because of its wide distribution and associated vegetation. Consumption of oak leaves, buds, catkins (flowers), twigs, or acorns usually reduces animal performance and may lead to death. Negative effects of oak browsing are caused by various chemicals in the plants called tannins. Tannins are classified as either condensed or hydrolyzable. Condensed tannins can be broken down only in strong acids, whereas hydrolyzed tannins are easily degraded and can be absorbed into the blood stream.

Interpretations of tannin studies are confounded by many factors. Plants containing tannins may contain other toxins, and tannins added to diets may differ from those found in plants. Tannins can also interfere with fiber analysis. Despite these interpretational problems, tannins clearly reduce digestibility and affect animals with specialized or variable diets. Specific effects on animals are dose-dependent.

Condensed tannins bind with proteins, carbohydrates, starch grains, and intestinal bacteria, all of which are important for normal digestion, growth, and maintenance of ruminant animals. When these food components become attached to tannins, they are unavailable for digestion and animal performance is reduced. Dry matter and fiber digestion can be reduced by tannins, but reduced nitrogen (protein) digestion is more common. Tannins bind with numerous forms of proteins. These include dietary protein, microbial protein, tannin-binding salivary proteins (TBSP), and proteins recycled from the lining of the digestive tract. Reduced nitrogen digestion has been observed when tannic acid exceeded $6 \%$ of the diet.

Tannin effects on animals vary with 


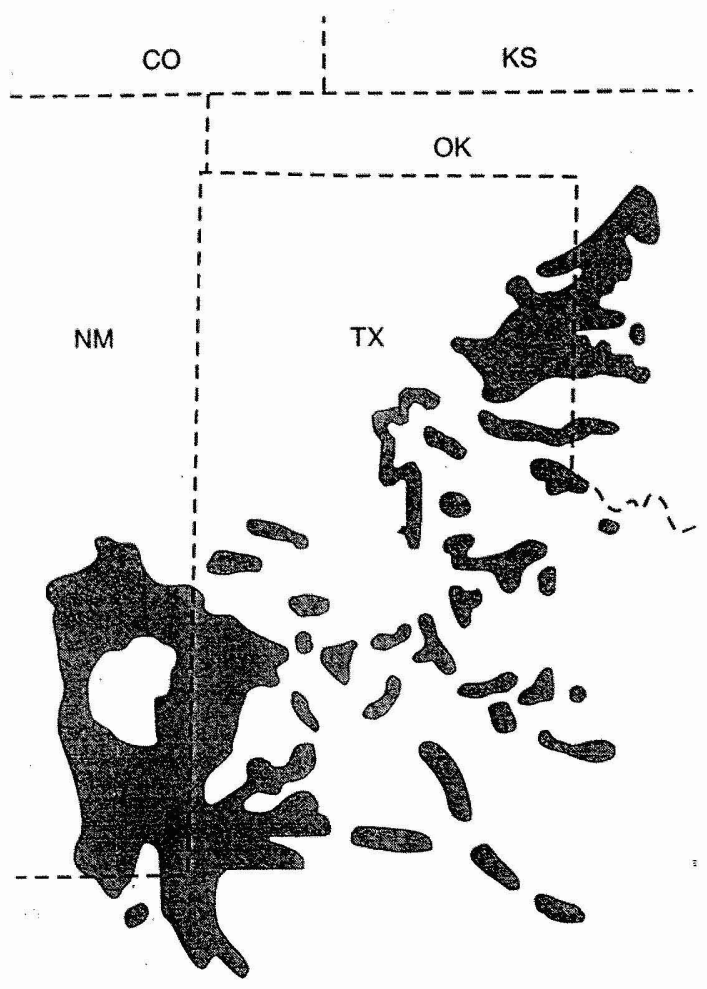

Fig. 1. Distribution of shinnery oak occurrence in Oklahoma, Texas, and New Mexico. (Borrowed from Peterson and Boyd 1998).

species and digestive system. Animals with a greater presence of TBSP, such as deer, are generally better adapted to tannin-rich diets. Tannins preferentially bind with TBSP, leaving other protein sources available for digestion. Cattle lack functional TBSP, so tannins are available to bind other forms of protein. Although the loss of protein is not as great for animals producing TBSP, protein digestion is still reduced by tannins.

Hydrolyzable tannins appear to have little or no effect on digestibility because they do not bind strongly with proteins. Hydrolyzable tannins can be degraded and absorbed, reducing digestion-inhibiting effects, but toxicity is increased. These tannins are broken down into gallic acid and pyrogallol, which directly attack the gut lining and cause hemorrahaging in the stomach and kidneys.

Animal performance is reduced when tannins exceed $5 \%$ of forage weight. Cattle have been reported to become ill when oak comprised more than $50 \%$ of the diet by weight and mortality was likely when oak exceeded $75 \%$ of total intake. However, these figures were based on tannin concentrations of 2 to
$6 \%$ in mature leaves. Tannins comprised 18 and $20 \%$ of shinnery catkins and buds collected in early April, when most poisoning occurs. So, illness and death may occur with one tenth to one third as much shinnery oak.

Shinnery can comprise significant amounts of cattle diets, depending on the growth stage and availability of associated species. Plumb and Pettit (1982) showed that oak consumption by cattle increased throughout the summer. Shinnery comprised $6 \%$ of the diet in June and $24 \%$ of the diet in August. Oak consumption by Angora and Spanish goats also increased from $31 \%$ to $51 \%$ as preferred forages were reduced between June and August (Villena et al. 1987). Shinnery oak consumption is often greatest in March and early April, when oak buds provided most of the green forage.

\section{Symptoms}

Tannins affect animal performance long before symptoms of toxicity become evident. Visible symptoms of oak poisoning occur in three stages, the first of which appears only after several days of oak consumption. The first stage is marked by dark, dry feces with mucus and blood, reduced appetite, and constipation. These symptoms are followed by bloody diarrhea, frequent urination, and animals remaining near water. In the final stages, cattle will have a rough coat, dry muzzle, reddish urine, and possibly watery swellings on their underside. Symptoms last 3 to 10 days before the animal either recovers or dies. Internally, the primary lesions are inflammation of the kidneys and stomach. The abomasum and small intestines are often inflamed and ruptured as well.

\section{Prevention and Treatment}

Oak poisoning occurs when oak is the main source of forage. Herbaceous forage is often limited before spring greenup, in early fall, or during drought. Most oak poisoning occurs during the first 30 days after oak leaves emerge. Green herbaceous forage is limited during this period and tannin concentration is greatest in young oak leaves and twigs. Pigeon et al. (1962) found young and mature shinnery oak leaves were 15.1 and $4.2 \%$ tannin, respectively. Physical alterations of oaks may also increase the risk of poisoning. Tannin concentration is greater in oaks that have been cut and in young leaves that have been killed by frost. Poisoning during fall is typically limited to years of abundant acorn production. Calves are more likely to be poisoned by oak than mature animals, although it is not clear whether they are less capable of coping with tannins, or if they are simply more likely to consume oak. Nursing calves may receive elevated doses because tannins concentrate in milk.

Poisoning can best be prevented by using moderate stocking rates and main-

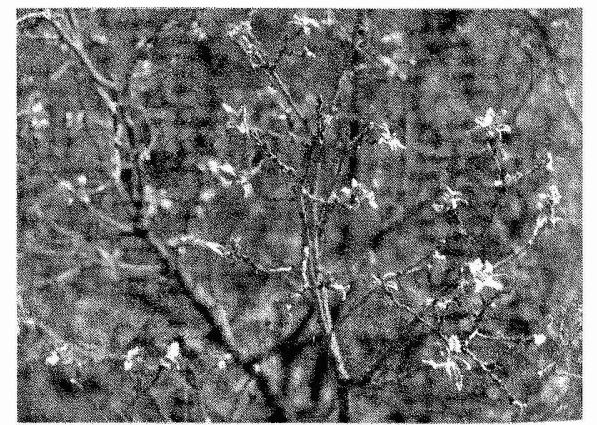


taining a diverse forage base. Dollahite et al. (1966) suggested supplementing calcium hydroxide at $10 \%$ of total intake as a preventative measure. Calcium hydroxide seems to prohibit tannin absorption by forming insoluble complexes. Other alternatives include denying cattle access to shinnery-dominated range for the first 30 days of oak foliation, removing cattle if frost blackens oak leaves, or supplementing high-energy and high-protein feeds. Poisoned animals should be given a mild laxative and adequate access to food and water until recovery is complete.

Cattle will not consume toxic levels of oak if desirable forage is in ample supply. However, during drought conditions, careful herd monitoring and preventative management are recommended. Animal performance is affected long before visible symptoms become apparent. Oak poisoning is largely a symptom of overstocking and poor range condition. Additional preventative measures include deferment of spring grazing and supplementation with calcium hydroxide.

\section{References}

Cheeke, P. R. 1998. Plants and toxins affecting the gastrointestinal tract and liver, pp 327-328. In: Natural toxicants in feeds, forages, and poisonous plants.. Interstate Publishers, Danville, Ill.

Dollahite, J. W. 1961. Shin oak (Quercus havardii) poisoning in cattle. Southwestern Vet. 14:198-201.

Dollahite, J. W., G. T. Housholder, and B. J. Camp. 1966. Effect of calcium hydroxide on the toxicity of post oak (Quercus stellata) in calves. J. Amer. Vet. Med. Assoc. 148:908-912.
Foley, W. J., G. R. Iason, and C. McArthur. 1999. Role of plant secondary metabolites in the nutritional ecology of mammalian herbivores: how far have we come in 25 years? pp 130-209. In: H. G. Jung and G. C. Fahey, Jr. (eds.) Nutritional Ecology of Herbivores. Proc. 5 th Int. Symp. on the Nutr. of Herbivores. Amer. Soc. Anim. Sci., Savoy, Ill.

Hagerman, A. E., C. T. Robbins, Y. Weerasuriya, T. C. Wilson, and C. McArthur. 1992. Tannin chemistry in relation to digestion. J. Range Manage. 45:57-62.

Harper, K. T., G. B. Ruyle, and L. R. Rittenhouse. 1988. Toxicity problems associated with the grazing of oak in intermountain and southwestern U.S.A., pp 197-206. In: L. F. James, M. H. Ralphs, and D. B. Nielson (eds.) The ecology and economic impact of poisonous plants on livestock production. Westview Press, Boulder, Colo.

Kingsbury, J. M. 1965. Deadly Harvest-A Guide to Common Poisonous Plants. Holt, Rinehart and Winston, N.Y.

Lindroth, R. L. and G. O. Batzli. 1984. Plant phenolics as chemical defenses: effects of natural phenolics on survival and growth of prairie voles (Microtus ochrogaster). J. Chem. Ecol. 10:229-244.

Murdiati, T. B., C. S. McSweeney, R. S. Campbell, and D. S. Stoltz. 1990. Prevention of hydrolysable tannin toxicity in goats fed Clidemia hirta by calcium hydroxide supplementation. J. Appl. Toxicol. 10:325-331.

Panciera, R. J. 1978. Oak poisoning in cattle, pp 499-506. In: R. F. Keeler, K. R. Van Kampen, and L.F. James (eds.) Effects of poisonous plants on livestock. Academic Press, N.Y.

Plumb, G. E. and R. D. Pettit. 1982. Grazing study in sand shinnery oak range, pp. 49-50. In: F. S. Guthery and C. M. Britton (eds.), Research Highlights, Noxious Brush and Weed Control. Dep. Range and Wildl. Manage., Texas Tech Univ., Lubbock, Tex.
Peterson, R. S. and C. S. Boyd. 1998. Ecology and management of sand shinnery communities: A literature review. USDA For. Serv. Gen. Tech. Rep. RM-16. Washington, D.C.

Pigeon, R. F., B. J. Camp, and J. W. Dollahite. 1962. Oak toxicity and polyhydroxyphenol moiety of tannin isolated from Quercus havardii (Shin oak). Amer. J. Vet. Res. 23:1268-1270.

Robbins, C. T., A. E. Hagerman, P. J. Austin, C. McArthur, and T. A. Hanley. 1991. Variation in mammalian physiological responses to a condensed tannin and its ecological implications. J. Mammal. 72:480-486.

Robbins, C. T., T. A. Hanley, A. E. Hagerman, O. Hjelford, D. L. Baker, C. C. Schwartz, and W. W. Mautz. 1987. Role of tannins in defending plants against ruminants: reduction in protein availability. Ecol. 68:98-107.

Villena, F., J. A. Pfister, C. Villena, F. San Martin, and M. Maiga. 1987. Diet quality and composition, forage intake, and palatability of sand shinnery oak for goats, pp. 18-19. In: L. M. Smith and C. M. Britton (eds.), Research Highlights, Noxious Brush and Weed Control. Dep. Range and Wildl. Manage., Texas Tech Univ., Lubbock, Tex.

Zhicheng, S. 1992. Research on the pathogenesis of oak leaf poisoning in cattle. pp 509-516. In: L. F. James, R. F. Keeler, E. M. Bailey, Jr., P. R. Cheeke, and M. P. Hegarty (eds.) Poisonous Plants. Proc. 3rd Int. Symp. Iowa State Univ. Press, Ames, Iowa.

Authors are research assistant and professor, Department of Range, Wildlife, and Fisheries Management, Texas Tech University, Lubbock, Tex. 79409-2125.

Authors wish to thank Carlton Britton, Robert Mitchell, Corey Moffet, and Carlos Villalobos for their assistance. This is manuscript T-9-863, College of Agricultural Sciences and Natural Resources, Texas Tech Univ. 